\title{
The Relative Productivity Hypothesis of Industrialization: The American Case, 1820 to 1850
}

\section{Citation}

Goldin, Claudia, and Kenneth Sokoloff. 1984. "The Relative Productivity Hypothesis of Industrialization: The American Case, 1820 to 1850." The Quarterly Journal of Economics 99 (3) (August): 461. doi:10.2307/1885960.

\section{Published Version}

doi: $10.2307 / 1885960$

\section{Permanent link}

http://nrs.harvard.edu/urn-3:HUL.InstRepos:30703977

\section{Terms of Use}

This article was downloaded from Harvard University's DASH repository, and is made available under the terms and conditions applicable to Other Posted Material, as set forth at http:// nrs.harvard.edu/urn-3:HUL.InstRepos:dash.current.terms-of-use\#LAA

\section{Share Your Story}

The Harvard community has made this article openly available.

Please share how this access benefits you. Submit a story.

Accessibility 

1820 to 1850

Claudia Goldin

Kenneth Sokoloff

Working Paper No. 722
NATIONAL BUREAU OF ECONOMIC RESEARCH 1050 Massachusetts Avenue Cambridge MA 02138

July 1981

The authors have benefited from the comments of Richard Arnott, Atack, Fred Bateman, and Tom Wein. They are grateful to Jeremy copy of their sample af Tom Weiss for providing Sokoloff with a Manufactures. Goldin's research has firms from the 1850 Census of No. S0C78-15037. The research reported supported by NSF Grant research program in Development of the here is part of the NBER's ions expressed are those of the of the American Economy. Any opinNational Bureau of Economic Research and not those of the without the author's permission. 
The Relative Productivity Hypothesis of Industrialization: The American Case, 1820 to 1850

\section{ABSTRACT}

The American Northeast industrialized rapidly from about 1820 to 1850 , while the South remained agricultural. Industrialization in the child labor, who comprised about $45 \%$ during these decades by female and 1832. Wherever and children in the agricula

Our hypothesis of early industrialization is that such development proceeds first in areas whose agriculture, for various reasons, puts the "relative productivity" agricultural or traditional of females and children in the pre-industrial the proportionately greater will children increase, and the will the relative wages for females and economy produce.

A two-sector model which incorporates a difference in "relative productivity" between two economies is used to develop seven propositions relating to the process of early industrialization. Data from two early evidence for our hypothesis, demo 1850, and other sources provide productivity of females and childrenting, for example, the low relative and the increase in relative wages for the Northeast agricultural sector, We conclude that factors with foborers with industrialization. were instrumental in the initial adoption productivity in agriculture industrialization in general in the U.S., and we believe these results

Claudia Goldin

Department of Economics

University of Pennsylvania

3718 Locust Wa1k/CR

Philadelphia, PA 19104
Kenneth Sokoloff

11655 Mayfield Avenue, No. 6 Los Angeles, California 90049

(215) $243-7733$ 
"Extensive manufactures can only be the offspring of a redundant, at least of a full population."

". . . in general, women and children are rendered more useful, and the latter more early useful, by manufacturing establishments than they would otherwise be."

Alexander Hamilton, Report on Manufactures (1791), reprinted in F.W. Taussig, editor, State Papers and Speeches on the Tariff (1892), p. 3 and p. 19.

\subsection{Introduction: The Role of Females and Children in Industrial Development}

There are diverse and complex reasons why certain countries have industrialized early in their histories and why within countries there has been regional variation in industrial development. One contributing factor to the early industrial history of the U.S., which appears to have more universal significance, is the productivity of females and of children relative to that of men within the agricultural sector. The contributions of this factor, which we term "relative productivity," to the evolution of the factory system and to regional variation in industrial development have been substantially underrated, although they were clearly recognized by those living at the time. Our study focuses on the influence of the single factor "relative productivity," on the nature and the location of early industrial development in the U.S. We will show that the labor forces of early manufacturing firms in the U.S. were comprised 1 argely of females and children, that wages of females and children relative to adult men rose with industrialization, and that industrial development seemed to flourish in areas which previously had low relative productivities of females and children in the agricultural sector.

In countries having high birth rates, a significant proportion of the total population will be between ten and twenty-five years (35\% in the case of the U.S. in 1820 ), and the young will comprise an even larger fraction of the potential 
labor force. The efficient employment of the young and of women outside their child-bearing years can make a substantial difference in the standard of living of the entire populace. It is thus not surprising that the Industrial Revolution both in the U.S. and in Great Britain was, at least initially, powered by these laborers.

Prior to industrialization the relative productivity within the agricultural sector of the young and of females was low in the hay, wheat, and dairy regions of the North. But relative productivity was substantially higher in the cotton, sugar, rice, and tobacco regions of the South, where slavery had long been established and industrial development lagged behind that of the Northeast and differed in form. The ratio of manufacturing and mining output to that in agriculture in the non-South was almost nine times that in the South in 1860; the ratio of manufacturing and mining output to all commodity output in the non-South was about five times that in the South. 1

During the pre-industrial period, females and children in the Northeast were typically perceived and described as "redundant" laborers. The introduction of machinery and the factory system radically changed this view. By 1832 about $45 \%$ of the industrial work force in the American Northeast was young and female, although this percentage peaked not soon thereafter. Furthermore a remarkably high percentage of all young New England women were employed in manufacturing, even though the factory system was still in its infancy. As the manufacturing sector expanded, wages for females and the young relative to those for adult males rose rapidly. But as the century progressed various changes, including the large Irish immigration, served to increase the supply of unskilled workers and to slow the increase in this wage relative.

The period from 1820 to 1850 is generally viewed as encompassing the Industrial Revolution in the U.S. Although in 1850 the U.S. population was still 
primarily agricultural, the percentage of the labor force in that sector had decreased substantially in the three decades preceding, from $79 \%$ in 1820 to $55 \%$ by 1850 , and in the North, the primary area of industrial development, this percentage decreased even more dramatically, from $75 \%$ to $30 \%$ over this period. Significant changes occurred within industries regarding the nature of work and mechanization, particularly in cotton textiles. But many other industries, (e.g. iron, glass, paper, shoes), which witnessed far less technical change and mechanization, also saw increased scale of firm and division of labor during the first half of the nineteenth century.

Our findings encompass many aspects of early industrial development, but central to this more involved tale is a critical finding about the determinants of the location and nature of industrialization. Within a land rich country where, for various reasons, the relative price of unskilled male labor is high, the factory system will locate where it can utilize those individuals least productive in agriculture, and it will in general locate where their relative productivity is the lowest. This "relative productivity" hypothesis is the focal point of our study.

This hypothesis has important precedents, both in the "surplus labor theory" of W.A. Lewis (1958) and in the labor-saving technical change literature stimulated by H.J. Habakkuk's (1962) monograph. 2 But our framework differs from their's in fundamental ways. We distinguish among laborers in their productivity within the agricultural and traditional sectors at full employment. Our focus is on relative productivity within the class of laborers, and not on "cheap" or "dear" labor relative to capital and land. Our study also differs from past industry studies (e.g. Ware 1931) by utilizing the manuscripts of various censuses of manufactures. (See Note at end for descriptive material on these sources.) We therefore do not focus on a single industry and have a 
large and diverse enough sample to test hypotheses about the process of early industrialization that have previously been unexplored.

Section 2.0 presents a simple two good ( $A$ and $M$ ), two factor $\left(L_{m}\right.$ and $L_{f}$ ) model in which two economies ( $N$ and $S$ ) differ only as regards the technology used to produce the A good, thus incorporating a difference in "relative productivity." Such a difference in "relative productivity" between sectors and between countries is only one of many possible factors determining the degree and nature of industrialization. But because we strive to isolate the implications of this one factor, the construction of our model is sparse, and we have standardized the two economies in a particular way. In Section 3.1 we justify our assumption of low initial relative productivity of females and of children in the North with data from its pre-industrial period. Section 3.2 presents evidence on the effect of industrial development on relative wages, labor force participation rates, and the nature of the manufacturing production process. We sumarize our findings in Section 4.0 by reviewing the historical evidence we present on the seven propositions developed in Section 2.0 .

\subsection{A Two-Sector Model of Early Industrialization in America}

Consider two economies ( $N$ and $S$ ) facing the same relative output prices $\left(\rho=\mathrm{P}_{\mathrm{m}} / \mathrm{P}_{\mathrm{a}}\right)$, and having two inputs of given amounts, male labor $\left(\overrightarrow{\mathrm{L}}_{\mathrm{m}}\right)$ and female and child labor $\left(\overline{\mathrm{L}_{\mathrm{f}}}\right)$, which are not able to migrate between the economies. 3 The inherent differences between these two factors may be the result of physical strength, dexterity, job experience, maturity, skill, or cultural factors. In the pre-industrial economy there is only an agricultural good (A), which is relatively male labor intensive in comparison to the as yet unavailable or unprofitable manufacturing technology (M). Our notion of "relative productivity" is incorporated by assuming that the $\mathrm{N}$ economy has an agricultural technology 
which is more $\mathrm{L}_{\mathrm{m}}$ intensive, at any set of factor prices, than is the agricultural technology in the $\mathrm{S}$ economy. Each economy has a unique A good technology which cannot be transferred to the other.

The pre-industrial economies are illustrated in the Lerner-Pearce diagram of Figure 1. The isoquants $A^{N}$ and $A^{S}$ represent equal quantities and thus equal values of the agricultural good, assumed to be the same in the two economies and to be produced with homogeneous of degree one production functions differing in factor intensity. Ray OR gives the global factor intensity of the two economies, and the intersection at point $r$ on ray OR of the two agricultural isoquants implies that the two pre-industrial economies produce identical amounts of the A good at full employment. This standardization assumption ensures that any difference between the two economies in the industrialization process does not arise from an inherent inefficiency of one in the production of the A good.

The factor price ratio in the pre-industrial $\mathrm{N}$ economy, at full employment, is given by $\left(w_{f} / w_{m}\right)_{0}^{N}$, and it will be lower than that given by $\left(w_{f} / w_{m}\right)_{0}^{S}$ for the pre-industrial s economy. This difference in relative input prices at full employment in the pre-industrial economies is precisely what we mean by "relative productivity." It is even possible that $\left(w_{f} / w_{m}\right)^{N}{ }_{0}$ will be lower than some reservation wage ratio, say the dashed line $\left(\mathrm{w}_{\mathrm{f}} / \mathrm{w}_{\mathrm{m}}\right)$, which would imply that the supply of $\mathrm{L}_{f}$ schedule would have a flat portion of amount $\left(\mathrm{L}_{f} * \overline{\mathrm{L}_{f}}\right)$ at the reservation wage.

What happens when a manufacturing sector (M) is available to these traditional economies? We have assumed that the $M$ sector is, compared to both the $N$ and the $S$ agricultural sectors, $L_{f}$ intensive, at all factor prices. 4 Isoquant $M_{0}$ in Figure 1 represents a value of $M$ equal at the output price ratio $\rho_{0}$ to that of the A output given by isoquants $A^{N}$ or $A^{S}$. But $\rho_{0}$ is insufficient to induce 


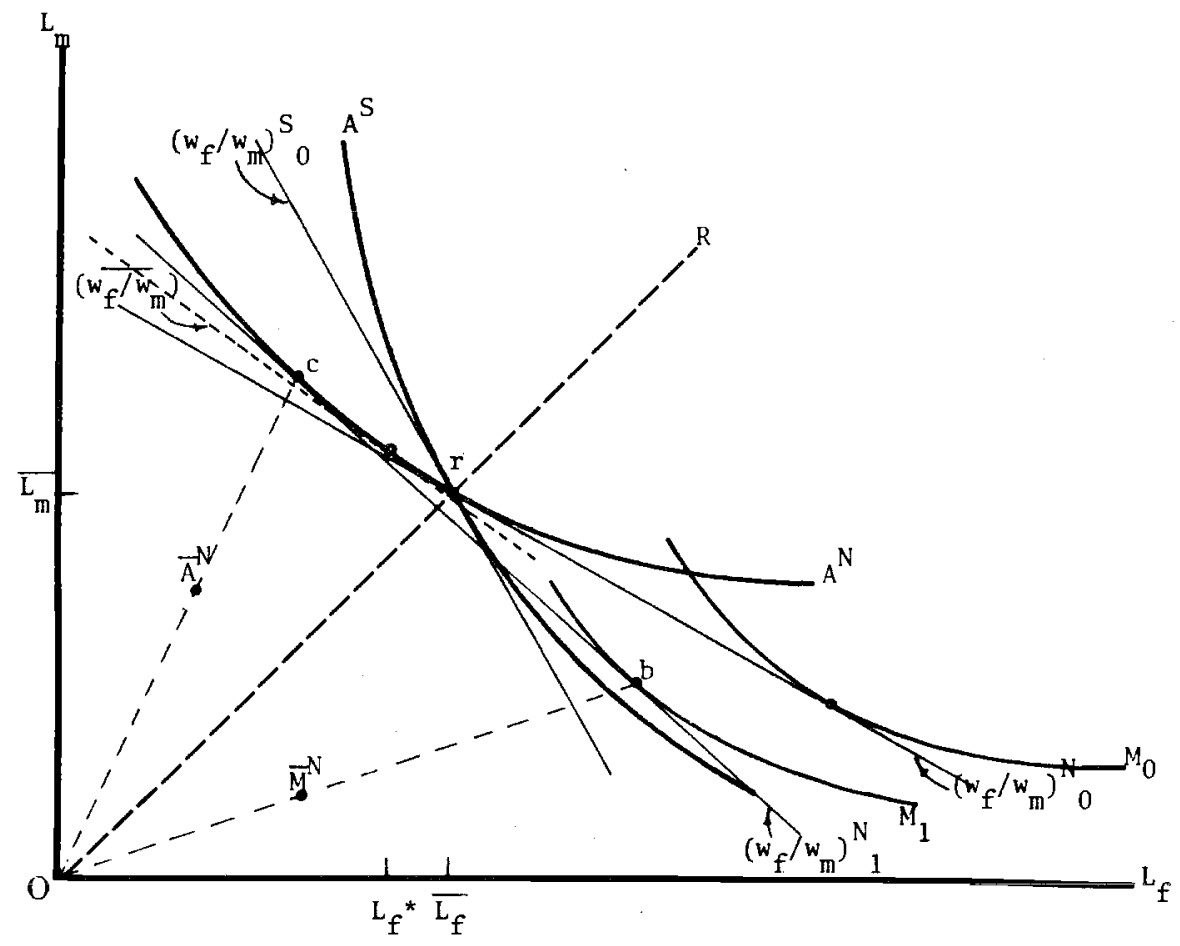

Figure 1: Lerner-Pearce diagram of pre-industrial economies and industrial $\mathrm{N}$ e conomy

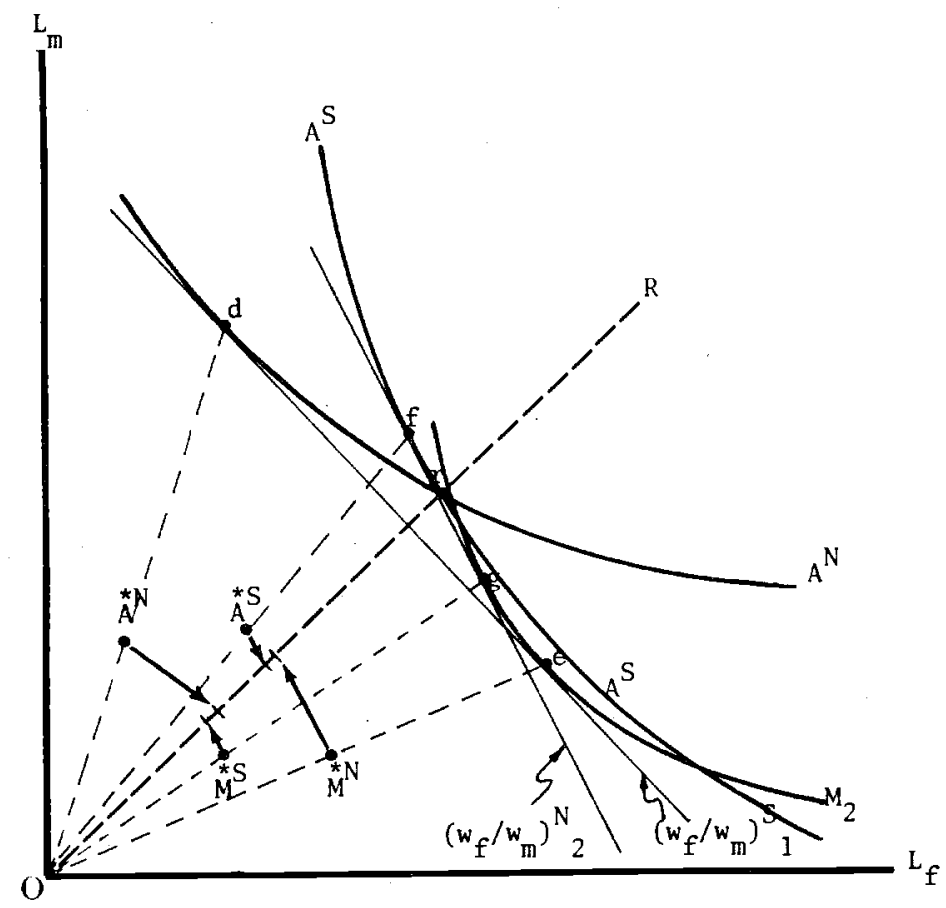

Figure 2: Lerner-Pearce diagram of industrial $\mathrm{N}$ and $\mathrm{S}$ economies 
either economy to industrialize. Consider a small increase in $\rho$, say to $\rho_{1}>\rho_{0}$, or alternatively, a small change in the manufacturing technology, sufficient to yield $M_{1}$ as the manufacturing isoquant, again with the same value of output as those given in the A sector. An increase in $\rho$, or a Hicks-neutral technical change in $M$, shifts isoquant $M$ toward the origin, that is it is equivalent to renumbering the $M$ isoquants.

These exogenous changes are now sufficient for the $\mathrm{N}$ economy to produce the $M$ good, but insufficient for the $S$ economy. Thus as $\rho$ increases or as technology advances, the $\mathrm{N}$ economy industrializes first. The new equilibrium for the $\mathrm{N}$ economy in Figure 1 will be a factor price ratio of $\left(w_{f} / w_{m}\right)_{1}^{N}$, production of $\overrightarrow{\mathrm{A}}^{\mathrm{N}}$ and $\overrightarrow{\mathrm{M}}^{\mathrm{N}}$, and factor intensities given by $0 \mathrm{c}$ in agriculture and $\mathrm{Ob}$ in manufacturing. Equilibrium in the $\mathrm{S}$ economy will involve the previous factor price ratio $\left(w_{f} / w_{m}\right)_{0}^{S}>\left(w_{f} / w_{m}\right)^{N}{ }_{1}$. Therefore during this initial phase, when only the $\mathrm{N}$ economy industrializes, the factor price ratio in the $\mathrm{N}$ economy rises, but does not exceed that in the $S$ economy. Indeed, the two economies will have the same input price ratio only at the point of specialization in $M$.

Now consider another Lerner-Pearce diagram, that in Figure 2, in which the $M$ isoquant has been shifted to the origin $\left(M_{2}\right)$ in response either to further increase in $\rho$ or to further neutral technical change. These changes are now just sufficient to induce the $S$ economy to produce the manufactured good. The new equilibrium for the $\mathrm{N}$ economy involves a factor price ratio of $\left(\mathrm{w}_{\mathrm{f}} / \mathrm{w}_{\mathrm{m}}\right)_{2}^{\mathrm{N}}$, production of $\mathrm{A}^{\mathrm{N}}$ and $\stackrel{*}{\mathrm{M}}^{\mathrm{N}}$, and factor intensities of od in agriculture and $\mathrm{Oe}$ in manufacturing. The factor price ratio in the $\mathrm{S}$ economy rises to $\left(w_{f} / w_{m}\right)_{1}^{S}>\left(w_{f} / w_{m}\right)_{2}^{N}$, but the percentage increase in the $N$ factor price ratio is greater than that for the $S$ economy. The $S$ economy produces $\AA^{*} S$ and ${ }^{*} S$, and for the case drawn ${ }_{M}^{*}>{ }_{A}^{*} S>A^{*}>{ }_{M}^{*} S$. The $N$ economy produces 
atsolutely more $M$ than does the $S$ economy, and also produces a higher ratio of (M/A) than the $S$ economy. The factor intensities in the $S$ economy are of and $\mathrm{Og}$, bounded by those in the $\mathrm{N}$ economy.

The following seven propositions summarize our characterization of the pre-industrial economies and of the general equilibrium impact either of an increase in the relative price of manufactured goods $(\rho)$ or of a neutral technical change inducing the same effect:

(1) Prior to industrialization $\left(\mathrm{w}_{f} / \mathrm{w}_{\mathrm{m}}\right)^{\mathrm{N}}<\left(\mathrm{w}_{\mathrm{f}} / \mathrm{w}_{\mathrm{m}}\right)^{\mathrm{S}}$;

(2) As the relative price of manufactured goods rises or as technical change advances, the $\mathrm{N}$ economy industrializes first;

(3) After the introduction of the $M$ sector in the $N$ economy only, $\left(w_{f} / w_{m}\right)^{N}$ increases but is $1 \mathrm{ess}$ than $\left(\mathrm{w}_{\mathrm{f}} / \mathrm{w}_{\mathrm{m}}\right)^{\mathrm{S}}$. After the introduction of the $\mathrm{M}$ sector in both econoinies $\left(\mathrm{w}_{\mathrm{f}} / \mathrm{w}_{\mathrm{m}}\right)^{\mathrm{N}}$ increases further and increases proportionately more than does $\left(w_{f} / w_{m}\right) S$;

(4) Factor intensities in the S economy are more alike between the two sectors than are those in the $\mathrm{N}$ economy;

(5) The M sector is relatively $\mathrm{L}_{f}$ intensive, and therefore relatively more $\mathrm{L}_{\mathrm{f}}$ than $\mathrm{L}_{\mathrm{m}}$ migrates to it;

(6) The $N$ economy produces absolutely more $M$ than does the $S$ economy and also produces a higher ratio of (M/A). If the complication of a reservation wag e is added:

(7) Before the introduction of the M sector, $\left(\overline{\mathrm{L}_{\mathrm{f}}} / \overline{\mathrm{L}_{\mathrm{m}}}\right)$ is higher in $\mathrm{S}$ than in $\mathrm{N}$, but the labor force participation rate of $\mathrm{L}_{\mathrm{f}}$ increases in the $\mathrm{N}$ economy with the introduction of the $M$ sector.

Some further remarks should be made regarding propositions (3) and (6). These propositions accurately represent the responses in the two economies when we consider the exogenous shock to have been a small increase in the relative price of manufactured goods or a small change in technical efficiency of $M$ production. If, however, we consider a global change, such as the introduction of a new technology, further qualifications would be needed. But since initial industrial development implies a small change around the point of specialization in agriculture, we believe these propositions to be valid 
characterizations of early industrialization.

There are two sets of implications from our analysis. One concerns differences between two economies that embrace a new sector, and one concerns the impact of industrial development within an economy. We focus primarily on the latter with respect to the North, but also use our analysis to explore the relative absence of industrialization in the South. ${ }^{5}$ The two-sector mode1 summarizes the essential outlines of industrialization during the Early Republic. Industrial development in the U.S. at the turn of the nineteenth century was fostered by production techniques that utilized new forms of capital equipment and that employed a greater division of labor and the factory system of production. The proximate cause of industrialization, though, was the increase in the relative price of manufactured goods with the cessation of trade during the Napoleonic Wars and the maintenance of a high relative price with the imposition of a tariff on manufactured goods. But it was only in the hay, wheat, and dairy regions of the American Northeast, where the wages of females and boys relative to those for adult men were initially low, that this industrial development flourished. 


\subsection{Relative Wages and the Unskilled Labor Market in Early Industrialization}

\subsection{Pre-Industrial Relative Productivities and Employment}

Both relative wages and 1 abor force participation rates for females and children were low in the pre-industrial Northeast, in apparent contrast to the general "scarcity of hands" and "dearness of labor" that characterized the late eighteenth century adult male labor market. As the above quotations indicate, Hamilton, like many of his contemporaries, 1 ooked toward this under and unemployed segment of the economy to provide industrial labor power. Both the low initial relative productivities of females and children and their related low labor force participation rates were to have profoundly influenced the nature of industrial development in the U.S.

Measures of relative productivity in agriculture during the pre-industrial Early Republic exist in only fragmentary form, and our understanding of the sources of such differences is somewhat limited. Our quantitative knowledge about relative wages in agriculture and in the traditional sector is given in Table 1, which presents data on the agricultural sectors of the North and the South at a time when industrial development was very limited and, in the North, during the period of increasing industrialization. The data from 1808 to 1815 for Massachusetts indicate the very low relative productivity of women and children (generally defined as less than sixteen years old) in the agricultural sector. Evidence for 1832 pertaining to areas somewhat removed from industrial development shows the same pattern.

Several difficulties have arisen in constructing these ratios for the pre-industrial economies. As industrialization spread, wage ratios in the agricultural sector rose, and care was taken to ensure that the wage ratios in agriculture reflected the pre-industrial relative productivities. The computation of all in-kind payments for male laborers working on monthly or yearly 
TABLE 1

Relative Wages for Females and Boys in the Agricultural and Traditional Sectors of Various Economies (with and without board)

\begin{tabular}{|c|c|}
\hline $\begin{array}{l}\text { Including a Value } \\
\text { for Board } a\end{array}$ & $\begin{array}{l}\text { Excluding a Value } \\
\text { for Board }\end{array}$ \\
\hline$w_{b} / w_{m}$ & $w_{b} / w_{m}$ \\
\hline
\end{tabular}

(1) U.S. Northeast

(a) Massachusetts 1808

1811

1815

(b) Middle Atlantic 1832

(c) Ohio

1836- 40

$\begin{array}{ccc} & 0.198 & \\ 0.288 & 0.366 & 0.149 \\ & & \\ & 0.260 & 0\end{array}$

(2) U.S. South

(a) Old South

1850

(b) Entire South

1860

1867

1868

0.584

0.559

0.573

0.446

0.438

0.483

(3) Egypt
c. 1965
$0.65-0.69$
$0.48-0.50$

$0.572-0.769^{c} 0.247-0.433^{c}$ 
Notes:

(1a) 1808, 1811: Carroll Wright, Sixteenth Annual Report of the Commissioner of Labor of Massachusetts, $(\overline{1885})$. This retrospective of wages and prices does not indicate whether or not board is included, but the absolute level of wages indicates that it must have been. In 1808 boys were given $1 \mathrm{~s} / \mathrm{day}=16.7 \phi /$ day and men $5 \mathrm{~s} 0.8 \mathrm{~d}=84.4 \phi$ per day or about $\$ 21.70$ per month. Adams has found that men were paid $\$ 16.50$ inclusive of board in 1808 in the Brandywine, (Donald Adams, "Workers on the Brandywine: The Response to Early Industrialization" Regional Economic History Working Paper, 1980, p. 22, Table 5). The figure given for female domestics in the Wright report does not appear to include a value for board, and one of $\$ 1 /$ week has been assumed. 1815: Wright gives 50 $\$ /$ week for females with boand and $86.8 \% /$ day for males without board. A six day week is assumed, as is $\$ 1.00 /$ week board for females. Males with board received $56 \$$ per day.

(1b) The figure for children is for board only and that excluding a value for board is zero. McLane Report (1832) respondents in New York counties almost unanimously stated that children in the agricultural sector earned only their board, if that. Typical of their statements are the following from the McLane Report, Vol. II ". . .children's wages are not worth any thing, but to make cotton goods," (p. 38), and "Children, under 16, cannot obtain wages; their board and washing is generally considered of about as much value as their labor " ( $p .77$ ).

(1c) 1836-1840: G. Holmes, (1912), Table 5: Ohio Farm Record of Wages Paid Butler County Ohio. Female help: wages per week; male labor: daily wages times 6. Means of ranges given used. The lower ratio uses the harvest wage.

(2a) Read off Figures 19 and 22 in R.W. Fogel and S.L. Engerman, Time on the Cross (1976), Vol. I. For comparability with the northern figures, on 1 y females between 15 and 29 years old have been considered and on $1 \mathrm{y}$ earnings from field production have been used. The earnings have been weighted by the age distribution of females working in the Hamilton Milis. Dublin (1979) gives this distribution as: $39 \%$ between 15 and 19 years and $61 \%$ between 20 and 29 years. The smaller number uses the peak male net hire as the denominator and the larger number uses a weighted average of male net hires, 15 years and older where the weights are the proportion in each group (Historical Statistics, 1976, p. 17). Boys are between 10 and 15 years old for the smaller estimate of $\left(w_{\mathrm{b}} / \mathrm{w}_{\mathrm{m}}\right)$; boys are defined as 15 year olds for the larger estimate for comparability with the (2b) series.

(2b) Unweighted averages for southern states from U.S. Department of Agriculture, Report of the Commissioner of Agriculture for the Year 1867 (Washington, 1868), p. 416. Boys were defined as not under 14 years old.

(3) Bent Hansen "Employment and Wages in Rural Egypt," American Economic Review (June 1969), Vol. LIX, p. 307. The first figure includes all villages in survey; the second includes on1y those with records for 50 weeks and over. 
contracts was another problem. Because male laborers on long-term contracts frequently received lodging in addition to board, we have constructed estimates only where we could get daily hires. Finally, some of the most persuasive evidence we have gathered on the relative cheapness of female wages in the traditional sector was of a qualitative nature and could not be included in Table 1 .

Numerous accounts of the early nineteenth century indicate that weekly wages for female domestics rose during the first third of the nineteenth century (Ware 1931, p. 241). Such accounts also indicate that male wages in agriculture did not increase over these years, and therefore that relative wages for females within the agricultural sector rose with increasing industrialization. Henry Carey (1835), in his comparative study of wages across industrial nations, noted that in the U.S. case "agricultural labour has not varied materially ... in its money price [from 1793 to 1833 ] ... the wages of men having been very steadily about nine dollars per month [with board, but] ... the wages of ... females have greatly advanced being nearly double what they were forty years since (p. 26)." Considerable strength is added to our quantitative evidence on relative wages in agriculture by the commentary of those who lived through the period and those who have studied it intensively.

In sharp contrast to the low relative productivity of females and children in northern agriculture are the data for the cotton and tobacco growing regions of the South, where wage ratios were approximately double. There are several factors that could account for this difference, among them that women in the North rarely worked in the fields and that the wage rates used for the North are those of domestics. ${ }^{6}$ Why females in the North did not work in the fields or even in dairying tasks is an issue of great complexity, but one which may be related to our explanation of differences in the agricultural production 
function. Differences in the relative productivity of boys between the North and the South probably arose from the physical strength required and the costly supervision needed in the farming chores of the Northeast. Cotton and tobacco agriculture tended to conserve both on supervision costs and strength for a number of reasons. Females and children were relatively more productive in crops requiring extensive cultivation such as cotton and tobacco, and cotton, in particular, favored the small in harvesting operations. Furthermore cotton picking allowed a piece rate system of self-supervision and was not only unaffected by incomplete harvesting, but also required harvesting over a long period as the bolls matured. 7

Because high relative wages for females in the South persisted into the post-bellum period (see line (2b) Table 1) and exist in cotton regions today (see line (3)), it does not appear that slavery was the dominant cause of the ante-bellum wage ratio differences. Indeed slavery may have been a comparatively more profitable labor system in areas whose dominant crops favored the utilization of the female and younger portions of the labor force, whose leisure, education, and home production were valued far less than in a free labor system. 8

Not only were the relative productivities of females and children low in the Northeast, but their employment also appears to have been below that considered, in the pre-industrial period, "fu11." While there are no formal estimates of pre-industrial 1 abor force participation rates, Hamilton spoke of manufacturing affording "the employment of persons who would otherwise be idle (p. 19)," the typical McLane Report respondent referred to the employment of "females who had little else to do (Vo1. I, p. 819)," and the view that "mill labor was ... largely composed of women and children who were otherwise 
unemployed (Ware 1931, p. 226)" has been accepted by most scholars of the Early Republic.

Regional variation in the process of industrialization has been attributed to many factors. Among them the most widely debated for the American case have been: capital market imperfections, political and cultural differences, and the relative efficiency of slaves in cotton and tobacco production. We have added another possible reason for the superiority of the North in the initial transition. When industrialization first took root in the North, it was fueled by abundant and relatively cheap female and child labor. The South may have had a large pool of unskilled labor, but it has no group whose relative productivity was low within the region.

The two-sector model has indicated that during the initial phase of industrialization, female labor would migrate to the industrial sector in a greater proportion than would male labor. In the North this is precisely what happened during the 1820 to 1850 period. The daughters of northern farm families left home to work in factories for relatively brief periods of time. This use of labor having a low product in agriculture encouraged the industria1ization of the Northeast. The impact of manufacturing and the factory system on relative wage rates and employment of females and children is the topic we next address. 
3.2 The Impact of Industrialization on Relative Wages and on the Unskilled Labor Market, 1820 to 1850

It has long been recognized that women and children played an important role in the early industrialization of both the U.S. and Great Britain, but the actual extent of their employment has not been fully appreciated. 9 Although we have no information on the pre-industrial labor force participation rates of females, the data that we have amassed, sketchy as they are, highlight a spectacular change in the labor markets of the Northeast during the period of early industrialization.

Over the two decades from about 1810 to 1832 , the percentage of young women (between the ages of 10 and 29) engaged in factory work increased from near zero to somewhere between $10 \%$ and $30 \%$, depending on the location in the Northeast. 10 In Massachusetts and Rhode Island, the states which industrialized most rapidly and for which we have the most reliable data, about $19 \%$ to $27 \%$ of all females 10 to 29 years old were reported in manufacturing employment in 1832. This figure increased in Massachusetts to about $40 \%$ by 1837 , if one also includes employment in the home production of palm leaf hats and other items. Using the same procedures for 1850 results in figures ranging from $27 \%$ to $33 \%$ for these states. Thus, at an early date in the nineteenth century the states of New England were employing a substantial fraction of their unmarried women in factory work. Because other occupations existed for young women, e.g. teaching, domestic service, these figures provide a lower bound to the actual labor force participation rates of this group and attest to the tightness of this early labor market.

Another statistic that indicates the importance of non-adult male labor in the process of industrialization is the percentage of the industrial labor force composed of women and children. As we pointed out in the introduction, 
this figure was higher during the early period of industrialization than it was after. For the states of the Northeast, about $45 \%$ of the industrial labor force was comprised of nonadult males in 1832 , but by 1850 this figure had been reduced to about $33 \%{ }^{11}$ A decomposition of the sources of the relative decline in female workers for Massachusetts over the period 1837 to 1850 indicates that the sectoral shift by industry in the total labor force was more important than was the decline of the employment of women within particular industries.

The high percentage of the industrial labor force composed of females and children during the initial period of industrialization indicates the extent to which individual firms substituted relatively cheap female and young labor for relatively expensive male labor. Traditional historical sources on early industrialization have pointed to the existence of different technologies within a wide range of industries, giving entrepreneurs a broad menu of factor proportions from which to choose. Although the substitution of unskilled labor and capital for skilled artisans is well known in the case of cotton textiles, the substitution of females and of children for adult males was also achieved in boots and shoes (Hazard 1921), wool (Cole 1926), glass (Davis 1949), and paper among other industries. The percentage of a firm's labor force that was composed of females and of children rose substantially from the small size class of one to five workers, to the intermediate class from six to fifteen workers. Thus, it was the change from the artisanal shop to the small factory that was behind the early utilization of women and children. While some of this substitution involved large amounts of capital, much involved merely an expanded division of labor, in the absence of the employment of a new and more capital intensive technology. 12

The substantial utilization of females and of the young within manufacturing and the large percentage of these groups in the population employed 
TABLE 2

RELATIVE WAGE RATES IN MANUFACTURING, for two regions 1832 and 1850
$\mathrm{w}_{\mathrm{f}} / \mathrm{w}_{\mathrm{m}}$

$$
\mathrm{w}_{\mathrm{b}} / \mathrm{w}_{\mathrm{m}}
$$

New England Middle Atlantic
New England Middle Atlantic

\begin{tabular}{|c|c|c|c|c|}
\hline $1832 a$ & {$\left[\begin{array}{c}.434 \\
{[.388-.479]}\end{array}\right.$} & $\begin{array}{c}.424 \\
{[.379-.468]}\end{array}$ & $\begin{array}{c}.408 \\
{[.304-.500]}\end{array}$ & $\begin{array}{c}.393 \\
{[.294-.482]}\end{array}$ \\
\hline $1832 \mathrm{~b}$ & $\begin{array}{c}.459 \\
{[.448-.470]}\end{array}$ & $\begin{array}{c}.451 \\
{[.438-.463]}\end{array}$ & {$[. .446-.503]$} & $\begin{array}{c}.431 \\
{[.358-.486]}\end{array}$ \\
\hline $1850 \mathrm{a}$ & {$\left[\begin{array}{c}.416 \\
{[.334-.497]}\end{array}\right.$} & {$\left[\begin{array}{c}.489 \\
{[.393-.585]}\end{array}\right.$} & & \\
\hline $1850 \mathrm{~b}$ & {$\left[\begin{array}{c}.440 \\
{[.388-.492]}\end{array}\right.$} & {$\left[\begin{array}{c}.483 \\
{[.426-.539]}\end{array}\right.$} & & \\
\hline
\end{tabular}

Sources and Notes:

1832a: The estimate of the female to adult male $\left(w_{f} / w_{m}\right)$ and boy to adult male $\left(w_{b} / w_{m}\right)$ wage ratios are derived from a set of wage regressions estimated over a sample of 853 manufacturing firms from the McLane Report (1832); See Tab1e 3. Because these wage ratios vary somewhat across industries, we have given the ranges in brackets. The average ratios given are the midpoints of the reported ranges in the case of $\left(w_{f} / w_{m}\right)$, and the average of the wage ratios estimated for the various manufacturing industries in the case of $\left(w_{b} / w_{m}\right)$.

1832b: These ratios utilize the 1832a female and boy wage figures, but are divided by 1832 wage rates for common laborers. The New England estimates is Lebergott's (1964, p. 541), adjusted for a value of $\$ 1.50 /$ week board. Lebergott's estimate for the 1832 Middle Atlantic common laborer wage appears too high and is inconsistent with other evidence. For example, it implies that common laborers were paid higher wages than were the employees of most manufacturing industries, and it also indicates that the nominal wage for common laborers fell in the Middle Atlantic between 1832 and 1850, while rising significantly in New England. Thus, instead of employing Lebergott's estimate of $96 \phi$ /day, we use a figure of $75.5 \$ /$ day, obtained from two independent methods. We have derived this estimate by applying the New England-Middle Atlantic wage differential from the regressions over manufacturing firms (in percentage terms) to the New England wage for common laborers. In addition, an average of the common laborer wage rates given by J. Zabler, "Further Evidence on American Wage Differentials," Explorations in Economic History (1972), and D. Adams, "Wage Rates in the Early National Period: Philadelphia, 1785-1830," Journal of Economic History (1968) yields an almost identical estimate. 
by industry suggest that relative wage ratios may have been radically altered by industrialization. We therefore turn to a discussion of how early industrialization affected relative wages, which were initially quite low in these regions. Our estimates of relative wage ratios in manufacturing are given in Table 2, where we summarize findings from our more comprehensive study of early industrialization (Goldin and Sokoloff, 1981).

Albert Gallatin, twice Secretary of the Treasury, noted in 1831 that "female labor employed in manufactures appears from the rate of their wages to be more productive than if applied to the ordinary occupation of women." 13 Our principal finding confirms this supposition; wherever manufacturing and the factory system evolved, the relative wages of females and of boys rose. The wage data underlying Table 2 have been derived primarily from a set of wage regressions on firm-1evel data, of which that for 1832 is given in Table 3. Two wage ratio estimates are presented in Table 2 for each year: figure 'a' uses our estimate of male wages in manufacturing and figure ' $b$ ' uses estimates of a more uniform worker's wage, that of a 'common laborer.' Estimate ' $b$ ', which we prefer, is constructed to standardize male workers, because industrialization may have widened the wage distribution for adult men (Williamson and Lindert, 1980) although the majority of men were not industrial workers.

Table 2 continued

1850a: The estimates of $\left(w_{f} / w_{m}\right)$ are derived from a set of wage regressions run over a sample of firms from the Census of Manufactures for 1850; see Goldin and in brackets, and the point . The range of ratios, among industries, is given census did, and the point estimate is the midpoint of the range. The 1850 boys, and not require manufacturers to distinguish between adult males and of adult males with boys, we have used $\left(w_{b} / w_{m}\right)$. Because of this aggregation which employed few boys.

1850b: The $\left(\mathrm{w}_{\mathrm{f}} / \mathrm{w}_{\mathrm{m}}\right)$ figures are based on the $1850 \mathrm{a}$ female wage estimates, but utilize Lebergott's (1964) estimates of the wages for common laborers in 1850
for the male wage. 


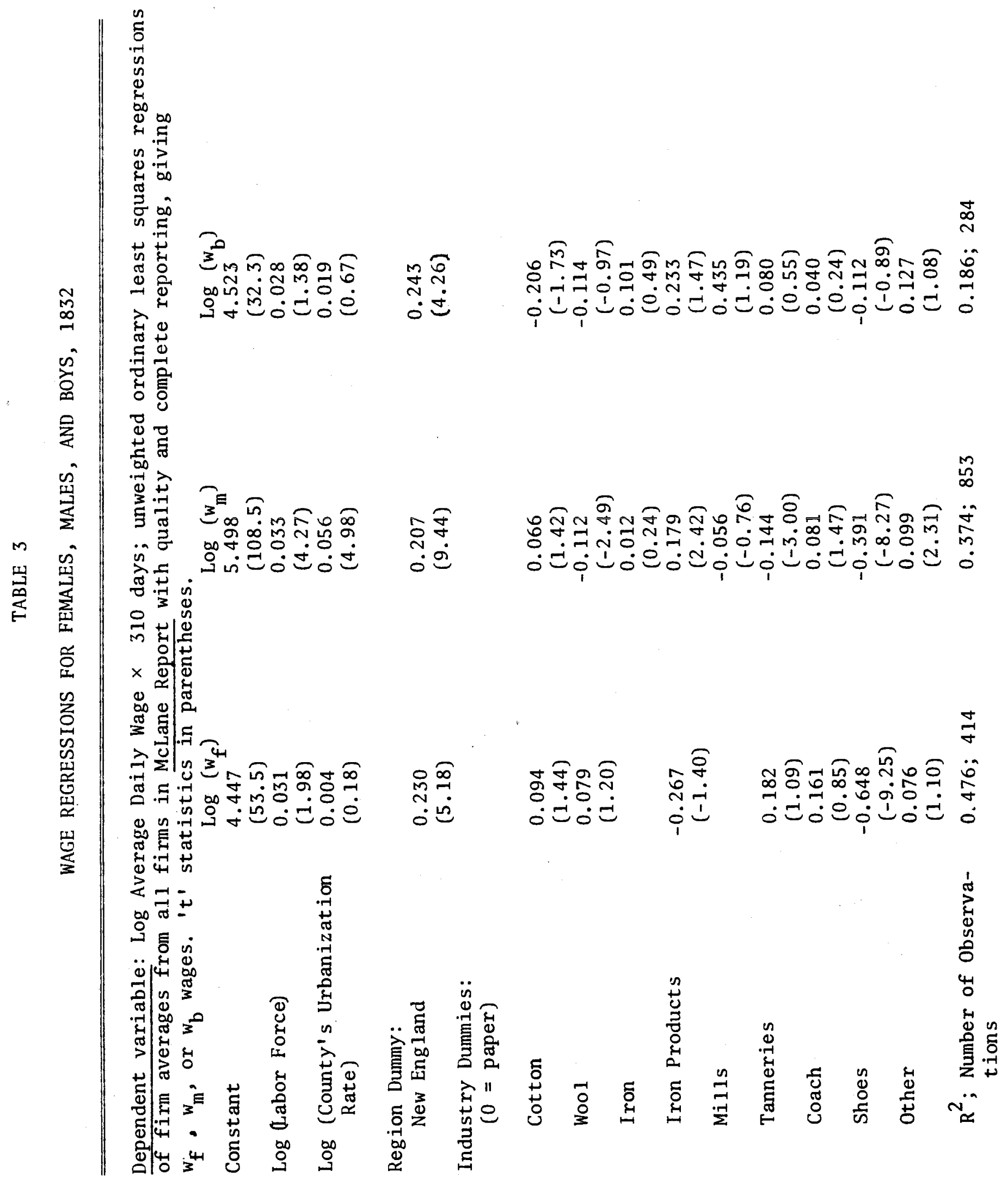


The usual assumption of homogeneous labor is a more accurate description of the female and child labor force than of adult males.

Compared to the relative wages in Table 1 those for females in Table 2 are about $50 \%$ greater and indicate an increase in this ratio of about $1.6 \%$ per annum from 1815 to $1840 .^{14}$ The relative wage of females in manufacturing increased even more later in the nineteenth century, reaching a long term level of about 0.58 by 1880 , where with only one decline (the early 1930's) and one large increase (World War II period) it has remained. ${ }^{15}$ Therefore, in the brief period of early industrialization the relative wage of females increased at a remarkable rate, achieving a value that was $83 \%$ of its long run figure, as opposed to that of the traditional sector which was only $52 \%$ of it.

The estimates of $\left(\mathrm{w}_{\mathrm{f}} / \mathrm{w}_{\mathrm{m}}\right)$ in Table 2 may even understate the impact of industrialization on relative productivities, because they are not fully adjusted for changes in the composition of the female labor force. Girls, that is females below the age of sixteen years, comprisedfrom 20 percent to 25 percent of the total female workforce in manufacturing in 1832, and their wages were about 60 percent of a full-grown female worker's. But young girls were rarely hired in the agricultural and traditional sectors since their absolute wages barely covered their board, and the use of young workers was reduced considerably in the later periods of manufacturing. The bias from including girl wages in the 1832 female average is on the order of 10 percent, and thus our best estimate of an adult female wage divided by an adult male wage increases to about $0.500^{16}$

What accounted for the rise in relative wages in advancing industrialization? We suggest in Section 2.0 that the explanation could be found in the implications of a simple two-sector model. The division of labor and adoption of certain 
machinery in the industrial sector enabled both greater substitution of females (unskilled) for males in manufacturing and relatively greater female (unskilled) labor intensity. It might also be claimed, particularly during this early period, that factory labor had to be compensated for harsher conditions, longer hours, and more days per year than in the agricultural sectors. Although there may be some truth to this statement, our findings indicate that females and children were compensated, percentage-wise, to a greater degree than were adu1t males, and thus there would still be an unexplained asymmetry.

While the regressions for 1832 in Table 3 do indicate that female wages rose with the size of the firm, male wages rose as well and in approximately the same proportion. ${ }^{17}$ The vast majority of these firms, particularly in textiles, operated the maximum number of hours per day and about 310 days per year, regardless of size. The increase in wages by size of firm, rather than capturing a "satanic mill" differential, probably measures compensation for additional living costs incurred away from home and for the costs of vacation travel back home. Furthermore, the differential by size of firm is insufficient to reverse the contention that relative female and child productivity rose with increasing industrialization. 18

It should also be stressed that farm work was highly demanding, perhaps requiring even more days per year than did manufacturing employment. Wage ratios $\left(w_{f} / w_{m}\right)$ in the agricultural sector closely resembled those in industry, rising during both this period and at other times throughout the century, as might be expected in a competitive labor market. ${ }^{19}$ The fact that relative wages rose in the agricultural sector is prima facie evidence that the increase in relative wages observed in manufacturing is not solely accounted for by various types of compensatory payments to females. 
Industrialization not only increased relative wages, it also served to increase greatly the participation of females and the young in the market economy, a factor of perhaps even greater importance. One would expect, therefore, that during the early years of industrialization relative wages might have been affected somewhat less, since labor supply would have been rather elastic. In terms of the two-sector model, the observed movement would be from $\left(w_{f} / w_{m}\right)$ to $\left(w_{f} / w_{m}\right)_{l}^{N}$, thus understating the increase in relative productivity at full employment. The decrease in the price of cotton textiles and various other previously home-produced goods, may have served in addition to lower the reservation wage of females. Thus the increase in relative wages that we record for the early nineteenth century is even more impressive. It should also be noted that wage ratios were somewhat higher in New England than in the Middle Atlantic in 1832 but that by 1850 a noticeable erosion had taken place in the wage ratio for New England, while that for the Middle Atlantic continued to rise. The decline in relative wages for females in New England in 1850 appears to have been the result of the large Irish immigration to cotton mill towns and the first major substitution of boys and men for young women in various industries.

We have followed through the implications of the two-sector model for the case of the North, and have shown that both relative wages and labor force participation rates increased for females and children. The most important evidence with respect to our hypothesis as applied to the South is that industrial development was rather limited in that region. We have somewhat less to report on the form that industrial employment took in that region during the Early Republic. Evidence for both regions from the 1850 Census of Manufactures indicates that factor proportions between the agricultural and industrial sectors differed more in the North than in the South, as 
predicted by the two-sector model. A precise comparison is hindered by the fact that global factor proportions differed between the two regions. A related indicator is the size distribution of firms by industry, since a more intricate division of labor was frequently accompanied by the use of females and children. In 1860 average employment in boots and shoes, and cotton textiles was consiaerably lower in the South than in the North, but in industries that rarely used females and children (machinery and lumber) the South had more laborers per firm (Bateman and Weiss 1981, p. 53). Another indication of the inherent differences in the regions is that when industrial development did come to the South in the form of cotton textiles, the family labor system was utilized as it had been in Great Britain. Thus females and children, although employed by cotton textiles in the South, formed a smaller percentage of its labor force than they had done in the North earlier in the century. 


\subsection{Concluding Remarks}

Throughout our discussion of the historical evidence we have pointed to an empirical verification of our "relative productivity" hypothesis. Each of the seven propositions we developed in Section 2.0 has been explored with our data on, for example, relative wages and factor intensities. To unify the discussion, we summarize the empirical evidence bearing on each of the propositions:

(1) In the pre-industrial North the relative factor price $\left(w_{f} / w_{m}\right)$ was quite low, ranging from about 0.30 to 0.35 , while in the South this ratio $\mathrm{f}_{\mathrm{m}}$ was consider-
ably higher, with a mean of about 0.58 ;

(2) The Northeast industrialized rapidly from 1820 to 1850 , while the South remained agricultura1;

(3) The relative factor price $\left(\mathrm{w}_{\mathrm{f}} / \mathrm{w}_{\mathrm{m}}\right)$ rose with industrial development in the North, achieving a value of about 0.50 during the early period, but it was still less than that in the agricultural South;

(4) Females and children comprised a large percentage of the northern manufacturing labor force, and although their employment was associated with increasing mechanization in certain industries, the adoption of an intricate division of labor expanded their employment in many others. It is therefore important to note that firms in the industrial sector of the South were considerably smaller than those in the North;

(5) Female labor migrated to industry in the North in relatively greater numbers than did male labor, and they were able to migrate separately from men because they were young, single women who only temporarily left their rural families;

(6) The value of manufacturing output in the North greatly exceeded that in the South, and the ratio of manufacturing and mining to agricultural output for the non-South states was 8.7 times that for the South in 1860; and

(7) In the industrial countries of New England, a surprisingly large fraction of the potential female labor force was employed in manufacturing, and such employment substantially increased the participation of fenlales and children in the market economy.

One may wonder why these phenomena have gone largely unappreciated. There are several equally worthy responses. In the first place, they have not been entirely neglected. Various industry studies, particularly of cotton textiles, have hinted at some of our general results. But a paucity of data has hampered 
previous scholars, and none was able to recognize fully the universal nature of the employment of females and children in the Early Republic. Furthermore, although the first half of the nineteenth century can well be viewed as the Industrial Revolution, various aspects of the industrial sector and of unskilled labor markets were to change so markedly after 1850 that the initial features we have detailed were to become relatively forgotten ones. Finally, our interpretation of the changes in relative wages and employment by using a two-sector model of industrialization weaves each of the seven propositions into a more coherent story of economic change than has previously been suggested. In conclusion, factors with low relative productivity in agriculture were instrumental in the initial adoption of the factory system and of industrialization in general in the U.S., and we believe these results are applicable to contemporary phenomena in developing countries. 


\section{FOOTNOTES}

${ }^{1}$ See Stanley Engerman, "The Economic Impact of the Civil War," Table 1, in S. Engerman and R. Fogel, editors, The Reinterpretation of American Economic History (1971). A11 commodity outputs are expressed in 1879 prices. The ratio of manufacturing output to all regional income for the Northeast was 2.7 times that in the South.

2 Habakkuk (1962) hypothesized that land abundance in the U.S. provided the critical difference between its industrial development and that of England. Simple two-sector, three input models (e.g. Clarke and Summers, 1980) suggest that the Habakkuk thesis may be incorrect, since if the demand elasticity for agricultural goods is less than one, an increase in land will, under most reasonable assumptions, decrease the capital to labor ratio in manufacturing. We differ with both the original Habakkuk argument and the revision for two reasons: (1) other factors such as land ownership and differential land fertility could account for intercountry differences in factor returns to farming, and (2) it is our contention that the employment of women and children in the U.S. was responsible for some of the observed differences in machinery. Habakkuk recognized the importance of female and child labor in his discussion of the nature of capital (see p. 65 in particular), but this part of his analysis was ignored in the debate that followed.

3 The assumption concerning migration between the two economies is a reasonable one in the case of the U.S. because of slavery.

4 The difference between the $A$ and $M$ sectors in $L_{f}$ intensity may be due to a third factor, capital. Although capital may now be complementary to skilled labor it appears that capital was a substitute for skilled labor and human strength in the nineteenth century. This substitution was delayed in agriculture for 
various reasons, but when technology did alter agricultural work, it was hoped that it would raise the relative productivity of boys. Bidwell and Falconer (1925) note in their post-1840 section that "one of the great benefits anticipated from the introduction of agricultural machinery was the more complete utilization of boy labor, for it was thought that the work which formerly required strong men could then be done by means of machinery and boys (p. 275)."

${ }^{5}$ Our focus on relative productivity and therefore our standardization of the two economies direct attention from other possible differences between the two regions that could also account for their differential development. We ignore differences in the accumulation of capital and factors which would give the South an absolute advantage in agricultural production over the North.

${ }^{6}$ Bidwell and Falconer (1925) summarize their extensive reading of travellers' reports with the statement that: "In New England only men as a rule were to be seen in the fields, the women of the family assisting only occasionally in harvest time (p. 116)." Harriet Martineau, reviewing her wide ranging travels through the U.S. during 1834 to 1835 , states: "The German women are the only women seen in the fields and gardens in America, except a very few Dutch, and the slaves in the South" (Vol. 1, p. 299) and "It is not the custom in America for women (except slaves) to work out of doors" (Vol. II, p. 54), Society in America (New York, 1837). It is curious that New England women did not engage in much dairy work, as was the custom in the other dairy regions in America. On this issue see Bidwell and Falconer (1925), p. 163. 7Metzer's (1975) study of ante-bellum southern plantations indicates that slave children began picking cotton at age five and that "the number of days in which slaves were engaged in picking declined with age, and females picked for more days per season than males in each age group (p. 135)." Even though 
males (over age 16) had an absolute advantage over females in cotton picking, females had a comparative advantage and therefore picked a greater percentage of the mandays allocated to that task.

${ }^{8}$ It should also be noted that because northern women and children may have had reservation wages above the "full employment" equilibrium (see model in section 2.0), observed wage relatives are overstated for the $\mathrm{N}$ economy in comparison to that for $S$, where all slave labor was employed.

${ }^{9}$ Lebergott's (1964, pp. 125-129) perceptive discussion, which stresses the importance of female labor and changes in female wage rates in early cotton textile factories, is an exception.

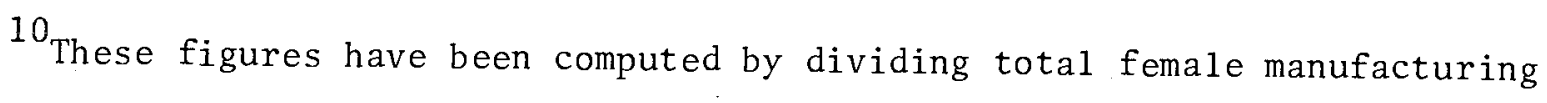
employment by the female population 10 to 29 years old. The 10 to 29 year old group is used because female workers were almost always unmarried. The 1832 data are from the McLane Report (1832), the 1837 figures are from the 1837 Statistics of Industry in Massachusetts, and all other data are from the relevant U.S. Census of Manufactures. Additional information about the data can be found in Goldin and Sokoloff (1981).

Manufacturing, Labor Force Participation Rates, 1832 to 1860

$1832 \quad 1837 \quad 1850 \quad 1860$

Connecticut $\quad .116 \quad .226 \quad .231$

Massachusetts $[.271 ; .187][.402 ; .297] .329 \quad .284$

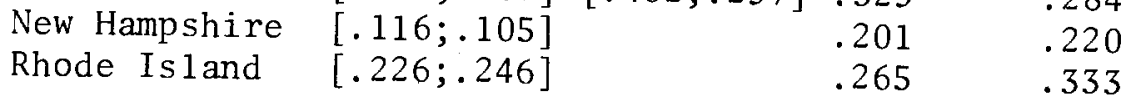

Where two figures have been given, the larger one includes women in home workshop
production. 
11 The 1832 figure for the Northeast adjusts the McLane Report (1832)

data for the under-enumeration of small firms, given industry mix, but

does not adjust for the possible bias toward industries with large firms.

There was no separate enumeration of boys from all males in 1850. Data

for Massachusetts from its industrial censuses indicate the decline in the

percentage of females occurred after 1837. The data for female and

child workers as a percentage of all workers in manufacturing for the states

of the Northeast are as follows:

$\begin{array}{lccc} & \text { Females } & \text { Boys } & \text { Females and Boys } \\ 1832 \text { Northeast } & 38.2 & 8.6 & 46.8 \\ 1850 \text { Northeast } & 28.3 & & \\ 1860 \text { Northeast } & 26.1 & & 27.1 \\ 1870 \text { Northeast } & \begin{array}{r}21.1 \text { (adults } \\ \text { only) }\end{array} & \end{array}$

12

The percentage of a firm's labor force that was female rose from $1.9 \%(3.7 \%)$

for 1 to 5 workers, to $12.8 \%(11.9 \%)$ for 6 to 15 , to $20.2 \%(32.6 \%)$ for $\geq 16$ in

1820 (1850, Northeast). The role of a greater division of 1 abor in determining

these percentages is made most forcefully by Davis (1949) in the case of the

glass industry, with regard to boy labor:

"When window glass was first manufactured in the U.S., it was customary not only for the blower to gather his own glass but also to blow, cut, and flatten it. In 1820 [larger firms]. . . frequently had assistants or apprentices who relieved the blowers of certain of the more minor and unskilled steps of the process. In time, the division of labor was greatly elaborated. . . (p. 48)"

13 Albert Gallatin, "Free Trade Memorial," reprinted in F.W. Taussig, editor, State Papers and Speeches on the Tariff (1892), p. 129.

${ }^{14}$ This growth rate uses an estimate of 0.30 for $\left(w_{f} / w_{m}\right)$ in 1815 and one of 0.45 for 1840 . 


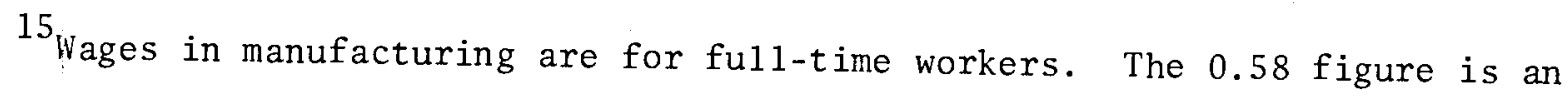
average of those for 1900 to 1929 and 1955 to 1960. The late nineteenth century data are from Long's reworking of the Aldrich Report, (C. Long, The Labor Force Under Changing Income and Employment, Princeton, 1958). Those for the twentieth century splice figures from A. Beney, Wages, Hours, and Employment in the U.S. 1914-1936, National Industrial Conference Board, (1936), Current Population Surveys, Series P-60 (1945 to 1960), and Lebergott (1964).

${ }^{16}$ From Table $2\left(w_{f} / w_{m}\right) \simeq 0.45$, where $w_{f}=\alpha w_{f_{c}}+(1-\alpha) w_{f_{a}}$, and $w_{f_{c}}=$ the wage for female children, $w_{f_{a}}=$ the wage for adult females, and $\alpha=$ the percentage of a11 female laborers who are girls. We estimate from the Mclane Report that from 20 percent to 25 percent of al1 female workers were girls (i.e., $\alpha=0.20$ to 0.25$)$ and from the Rhode Island returns of the McLane Report that $\left(w_{f_{c}} / w_{f}\right) \simeq 0.60$. Therefore, when $w_{f}=\$ 2.50$ per week, and $w_{m}=\$ 5.56$, ${ }_{f_{a}}=\$ 2.72$ per week (with $\alpha=0.20$ ) or $w_{f_{a}}=\$ 2.78$ per week (with $\alpha=0.25$ ). Thus $\left(w_{f_{a}} / w_{m}\right) \simeq 0.50$. On the issue of the ages of females working in the agricultural sector, McLane Report respondents frequently used the age category sixteen to twenty-four in describing female domestics (e.g. Vol. II, p. 46), and generally stated that younger children could barely earn their board. (See also Notes to Table 1 ).

${ }^{17}$ The use of size class dummies indicates that it was primarily the very large firms ( $>100$ workers) which had higher female wages, although female wages did begin to rise with firms having 25 or more workers. 
18

The implicit argument we are making is that the very large firms whose labor forces were overwhelmingly housed in "dormitories" had to pay a premium to all workers as compensation for the real costs of moving and for additional board. Firms locating in more rural counties, therefore, would have to attract workers from further distances and would have higher wages as a result. The Table 3 female regression, though, appears to indicate that the county urbanization rate was unimportant, but this results from the inclusion of industry dummies and the total labor force. The equation omitting these factors is:

$$
\begin{aligned}
& \log \left(w_{f}\right)=4.466+0.075 \text { New England dummy }-0.137 \log \text { (urbanization rate) } \\
& \text { (83.6) (1.44) } \\
& (-5.68) \\
& \mathrm{R}^{2}=0.83 ; \mathrm{N}=393 ; \text { " } \mathrm{t} \text { " } \begin{array}{c}
\text { statistics in } \\
\text { parentheses }
\end{array}
\end{aligned}
$$

Thus there is collinearity between large firms (mainly in textiles) and low rates of urbanization (water power sites). It should also be mentioned that regressions similar to those in Table 3 for 1850 (see Goldin and Sokoloff, 1981) indicate that size of firm was not a determinant of earnings. Migration and immigration during the $1840^{\prime}$ 's therefore eliminated the premium we measure for 1832 .

19. Adams, "Workers on the Brandywine: The Response to Early Industria1ization," (1980) finds nearly identical ratios of $\left(w_{f} / w_{m}\right)$ for agriculture and manufacturing in the Brandywine area of Delaware, which industrialized quite early in the nineteenth century. Data on agricultural wages on a rural Ohio farm (Holmes 1912, p. 16) indicate that the rate of increase of $\left(w_{f} / w_{m}\right.$; with board) from $1836-40$ to $1885-91$ was about $1.26 \%$ average annually. More extensive data from the early twentieth century show that relative wages in agriculture were approximately equal to those in manufacturing, e.g. in $1906\left(w_{f} / w_{m}\right)=0.565$ in the North Atlantic states, for hiring by the day, without board (Holmes 1912, p. 41 and p. 68). 
Bateman, Fred and Thomas Weiss, (1981). A Deplorable Scarcity: The Failure of Industrialization in the Slave Economy, Chapel Hill, University of North Carolina Press.

Bidwe11, Percy W. and John I. Falconer. (1925). History of Agriculture in the Northern United States. Washington, Carnegie Institution of Washington.

Carey, Henry C. (1835). Essay on the Rate of Wages: With an examination of the causes of the differences in the condition of the labouring populations throughout the world. Philadelphia.

Clarke, Richard and Lawrence Summers. (1980). "The Labour Scarcity Controversy Reconsidered," Economic Journal (March).

Cole, Arthur Harrison. (1926). The American Wool Manufacture. Two Volumes. Harvard University Press.

Davis, Pearce. (1949). The Development of the American Glass Industry. Harvard University Press.

Dublin, Thomas. (1979). Women at Work: The Transformation of Work and Community in Lowe11 Massachusetts, 1826-1860. Columbia University Press.

Goldin, Claudia and Kenneth Sokoloff. (1981). "Women, Children, and Industrialization in the Early Republic: Evidence from the Manufacturing Censuses," National Bureau of Economic Research Working Paper, forthcoming.

Habakkuk, H.J. (1962). American and British Technology in the Nineteenth Century. Cambridge University Press.

Hazard, Blanche. (1921). The Organization of the Boot and Shoe Industry in Massachusetts Before $1 \overline{875}$. Harvard University Press.

Holmes, George. (1912). Wages of Farm Labor. Department of Agriculture Bullet in \#99. Washington, D.C.

Lebergott, Stanley. (1964). Manpower in American Economic Growth: The American Record Since 1800. McGraw-Hill.

Lewis, W. Arthur. (1958). "Economic Development with Unlimited Supplies of development. Oxford University Press.

McLane, Louis. (1832). Documents Relative to the Statistics of Manufactures in the U.S., Volumes I and II. U.S. Congress Serial Set $\# 222$ and 223 .

Metzer, Jacob. (1975). "Rational Management, Modern Business Practices, and Economies of Scale in the Ante-Bellum Southern Plantations, "Explorations
in Economic History (April). 
Ware, Caroline F. (1931). The Early New England Cotton Manufacture: A Study in Industrial Beginnings. Russe11 and Russe11.

Williamson, Jeffrey and Peter Lindert. (1980). American Inequality: A Macroeconomic History. Academic Press.

A Note on Our Sources:

We have relied extensively on two sources: the Documents Relative to the Statistics of Manufactures in the U.S., known as the 1832 Mclane Report, and the 1850 schedules of the Federal Census of Manufactures, sampled for the Northeast by Fred Bateman and Tom Weiss. There was no census of manufactures in 1830, and the 1832 document contains the answers to an extensive set of questions circulated to manufacturing firms by the Secretary of the Treasury, Louis McLane. Various problems exist in using each of these data sets. Most important among our concerns is that the 1832 data under-represent small firms, and the information on workers and their wages differs in coverage and definition from census to census. The McLane Report generally listed adult males separately from boys less than 17 years old, with females of all ages grouped together. Wages were typically given as a daily average for each group of laborers, a1though coverage and detail varied considerably by state. The 1850 labor force and wage data were given for males of all ages and for females of all ages separately, with no separate category for children. 